\title{
A COST BENEFIT ANALYSIS OF DELHI AIRPORT PPP PROJECT
}

\author{
Sumana Chaudhuri and Ranjan Chaudhuri'
}

\begin{abstract}
One of the central tenets of the cost benefit analysis (CBA) literature is the divergence between a project's financial returns and social evaluation of what is desirable from the larger economic priorities and social goals of development. This article focuses on building a base of CBA for Delhi International Airport Limited (DIAL) as a case for Brownfield PPP Airport Project in India. The process of evaluation of the relative merits of the project in terms of the accrued benefits and costs, serves as a template for future frame of reference in similar PPP airport projects.
\end{abstract}

\section{KEYWORDS}

Cost Benefit Analysis (CBA); Externalities; Shadow Pricing; Public Private Partnership.

${ }^{1}$ Durgadevi Saraf Institute of Management Studies, Mumbai, India. R S Campus, S V Road, Malad (West) Mumbai 400064, India. +919819892726, sumanachaudhuri2002@gmail.com; sumana.chaudhuri@dsims.org.in 


\section{INTRODUCTION}

Airports in India play a vital role in the development of the aviation industry in India. According to the Center for Monitoring Indian Economy (CMIE), the growth in air passenger traffic in India is estimated to have fast-tracked to 12.6 per cent in 2014-15 from the 6 per cent growth recorded in 2013 - 14. New airlines like Tata Airlines and Singapore Airlines JV called Vistaara and Air Asia taking off in Indian skies in 2014, coupled with a strong rise in domestic passenger traffic due to hefty discounts on fares by domestic carriers like Spice Jet, Indigo, Go Airways and Jet Airways in the past one year boosted this growth. Domestic passenger traffic accounts for 70-75 per cent of the total air passenger traffic in India.

During 2015-16, Indian airports are expected to handle 207.2 million passengers, 8.9 per cent higher as compared to 2014-15. Majority of this traffic would be concentrated in Delhi, Mumbai, Hyderabad and Bengaluru. A total of 151.8 million domestic passengers are likely to travel from the Indian airports as compared to 139.1 million estimated for 2014-15. This translates to a rise of 9.2 per cent (CMIE, 2015). The air traffic canvas is however much broader. India has a population of 1.2 billion. On a daily basis only $0.01 \%$ ( 1 in 10,000$)$ of the population uses an aircraft (MOCA, 2011). International visitors excluded the ratio would be even lower. This illustrates the enormous potential for air travel in a large and diverse country like India. The development in India is still at a comparatively early stage. While significant investments have been made and public private partnerships are proving successful, further investment is required in response to quickly rising demand for air travel and corresponding infrastructure on the ground and in the air. The modernized airports in Delhi and Mumbai only provide sufficient capacity for the next few years before further expansion or even a new airport is required. Greenfield airports hold enough capacity for the medium term future; however, the modernization of 35 smaller airports plus plans for more Greenfield airports will further stimulate air traffic growth quickly filling excess capacity at these airports.

While ACI predicts global air traffic to double within 15 to 20 years, traffic volumes will at least triple in India during the same period. The current plans for further modernization and expansion of the airport network in India are estimated at USD 10 billion. A similar or higher amount will be required to accommodate growth beyond 2015 (ACI, 2011). To secure financing and world class know-how, a first step was made by establishing public private partnerships for four Delhi, Mumbai, Hyderabad and Bangalore. However, to ensure the viability of the airport sector in the future more private sector involvement is essential. This article aims to primarily focus on the economic and social costs and benefits of PPP airport 
infrastructure project in India, where the special case of Delhi Airport Brownfield project is discussed in the light of Cost Benefit Analysis.

\section{REVIEW OF LITERATURE}

\section{a. Role of Infrastructure in Economic Growth}

Infrastructure services can be described as being of 'strategic importance' (Kay, 1993). Infrastructure plays like pillar for an economy to be sustainable. Sound infrastructure drives national competitiveness. An infrastructure project can usually be classified as a form of public good, because it has both non - rivalry and non - excludability properties. Non rivalry means the good can be used by another person at no additional or marginal cost; while non - excludability means it is not possible to exclude people from using the good even if they don't pay for it (Stiglitz, 2000). Recent trends in commercialization of infrastructure will be a shift from this model of non - rivalry and non - excludability. Infrastructure has some inherent characteristics like it entails a huge investment, large sunk cost and a long gestation period. So it is not possible for the government alone to bear the entire huge investment requirement for the infrastructure sector. The solution lies in privatization or the private participation in public infrastructure projects which is popularly termed as PPP.

The World Bank (1994) found evidence that the role of infrastructure in growth is substantial, and frequently greater than that of investment in other forms of capital. Spillovers arising from an infrastructure project are of a much larger order of magnitude than for many other activities (Threadgold, 1996). Aschauer (2001) pointed out that investment in public infrastructure has positive spillover effects on an economy's productivity and thus on economic growth. Also, Milbourne et al. (2001) found a positive effect on economic growth from public investment with particular evidence of gains from investment in transportation, communication and education. Recent studies confirm a statistically significant positive relationship between productivity and infrastructure and suggest that infrastructure may be a key determinant of comparative advantage between countries (Yeaple and Golub, 2002).

Infrastructure projects typically exhibit economies of scale, possibly leading to natural monopolies; they may be socially desirable but not privately profitable. To correct these failures governments may regulate private service providers or provide the services 
themselves. These government failures may actually exceed the market failures, favoring private provision as argued by Winston (2006).

Infrastructure services, in general, are becoming more commercially oriented (Grimsey and Lewis, 2002). There has been the perception that a move from 'tax payer pays' to 'user pays' (i.e. from ability to pay to the benefit principle) is likely to be associated with a better economic use of the services (Musgrave, 1959).

Infrastructure is also expected to play a more important role in the catching-up process of developing and transition countries, both of which are supposedly facing underinvestment. (Estache et al., 2002; Hirschhausen, 2002).

\section{b. Airport Infrastructure}

Over the past decade, across much of the world, there has been extensive reform of airports. In several cases, airports have been fully or partly privatized, and in other cases, they have been restructured as corporations. Ownership structure has been changed with a view to making airports more commercially oriented. Airport privatization has been and still is, on the agenda of national air transport policies of many countries throughout the world. Privatization may take many different avenues, ranging from a minor divestiture of airport companies by public shareholders (for example in Germany) to a complete sell-off of (former) public airports to private investors (for example in Australia). Privatization can be restricted to the operation of public infrastructure facilities by a private firm (for example in Bolivia), or it can also involve privatizing the airport's infrastructure (for example in the UK). (Wolf, 2008)

\section{c. Concepts of PPP}

The term "public-private-partnership" was probably originated in the USA initially referring to joint public private sector funding for educational programmes. The scope of PPP was broadened in the 1950s to include funding for utilities, but came into wider use in the 1960s to refer to public-private joint ventures for urban renewal. In the provision of infrastructure, PPPs can be conceptualized as "project-based" or "contract-based" arrangement, which gained importance in the early nineties (Yescombe, 2007). Ministry of Finance, Government of India defines PPP as: "A partnership between a public sector entity (sponsoring authority) and a private sector (a legal entity in which $51 \%$ or more of equity is with the private partner/s) for the creation and/or management of infrastructure for public purpose for a specified period of time (concession period) on commercial terms and in which the private 
partner has been procured through a transparent and open procurement system. (Department of Economic Affairs, Ministry of Finance, Government of India, 2007)"

\section{d. Cost Benefit Analysis of Infrastructure Projects}

Cost benefit analysis is concerned with the theory and application of criteria for appraising the desirability of investment decisions in the public sector, in terms of national objectives (Chawla, 1987). The fundamental economic problem facing most nations is the optimal allocation of scarce resources in competing projects. This involves making a rational choice between various alternative projects and selecting the best possible one according to the criterion of maximization of net societal benefit. Social Cost Benefit Analysis (SCBA) of projects should aim to establish two national objectives, increasing the total national income (growth objective) and improving the income distribution so as to make it more egalitarian (equity objective). The other objectives of SCBA are ensuring that a selected project subscribes to employment generation, self-reliance, balanced regional development, protection and improvement of environment.

Projects are to be evaluated by the extent to which they contribute to (benefits) or detracts from (costs) from the national objectives. If benefits exceed costs, the project is acceptable. The benefits are defined in terms of their national objectives, whereas the costs are opportunity cost, which is the benefit foregone by not using these resources in the next best investment decision available. The benefits foregone can be re-defined in terms of their impact on national objectives. In an ideal condition, where every information pertaining to competing alternative projects are available, the investments are usually made to the best possible projects.

\section{DATA SET}

For the purpose of the present study, DIAL has been chosen to represent CBA. DIAL has completed a large part of the capital expenditure earmarked for its first phase of airport expansion. Terminal T3 with annual passenger handling capacity of more than 30 million is already operational.

The present work is based on secondary data collected from Centre for Monitoring Indian Economy (CMIE), Airports Authority of India (AAI), Airports Economic Regulatory Authority 
(AERA) and National Council for Applied Economic Research (NCAER). The dataset for analysis is collected for the period $2006-2012$

\section{COST BENEFIT ANALYSIS OF DELHI AIRPORT PPP PROJECT}

The article focuses on building a base of CBA for Delhi International Airport Limited (DIAL) as a case for Brownfield PPP Airport Project in India. It may be worthwhile to mention that according to OECD Manual (Little Mirrlees Approach, 1968), UNIDO Guidelines (1972), World Bank's Guide to Practical Project Appraisal (1978), European Commission's Guide to Cost Benefit Analysis (2008) and similar such works on project evaluation discussed in the literature review observed that CBA is primarily meant for ex-ante appraisal of projects. However, it is argued that the use of the approach may be encouraged equally for ex-post evaluation of projects like Delhi Airport, to analyze why a particular project succeeded or failed.

\section{a. Schematic Representation of CBA}

A schematic representation of Delhi Airport is shown below

Figure 1: The Six Steps of Cost Benefit Analysis for DIAL

(Source: Adapted from Guide to CBA, EU, 2008; NCR stands for National Capital Region, India)

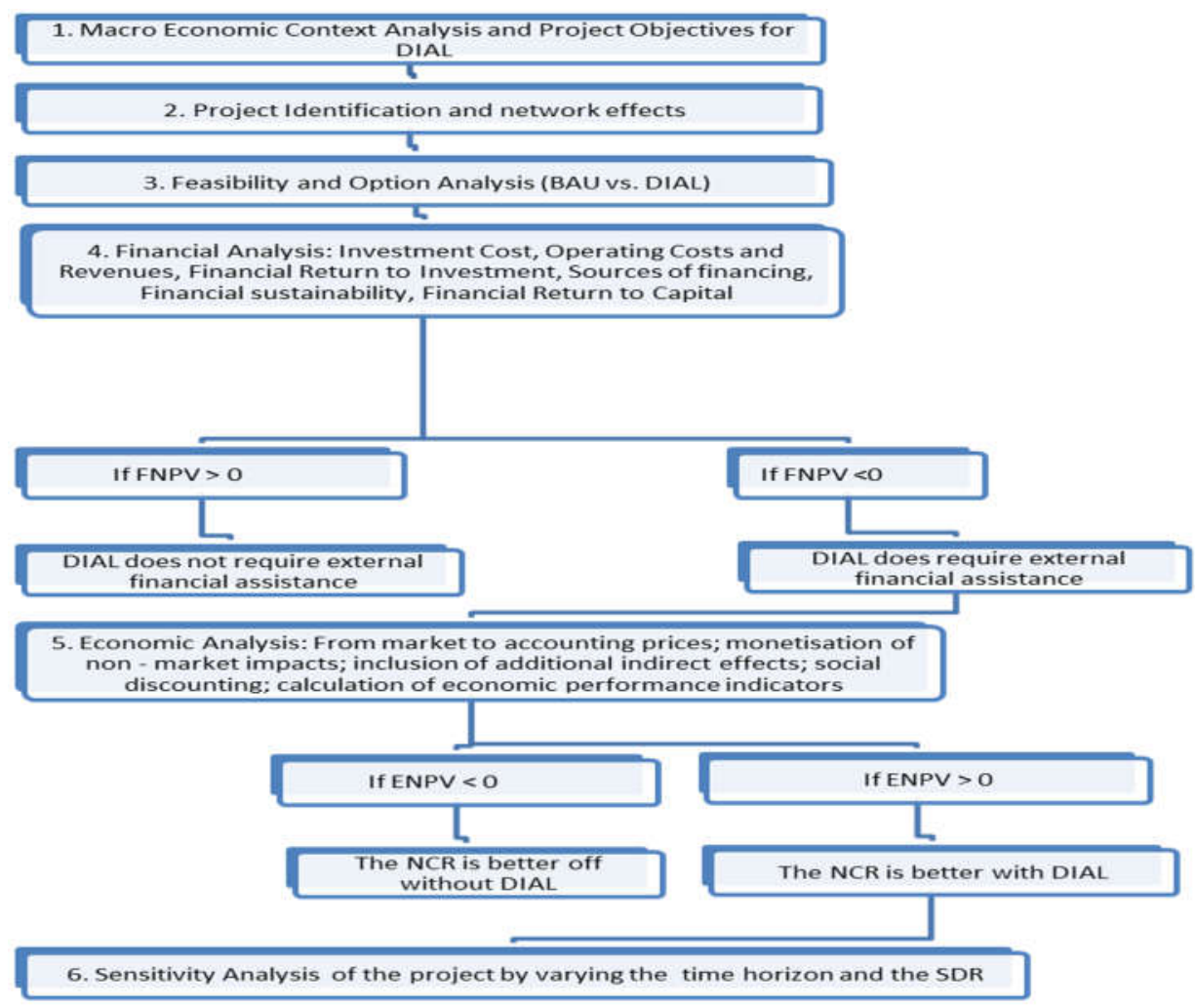




\section{b. Macro-economic context analysis and the project objectives}

The ascent of the 21 Century witnessed unprecedented growth in the quantum of trade in India, which were associated with heightened business activities and passenger movement for domestic as well as International traffic. As the national capital, Delhi naturally became the first port of call for many India inbound passengers. The growth in air travel was further escalated by the arrival of many low cost airlines, which touched base with Delhi either as hub port or as a routing station. These lead to a spurt of aviation growth focused on the national capital region and with the passage of time, aircraft, passenger and cargo movements took an incline that prompted Ministry of Civil Aviation to draft a blue print for expansion of the terminal building, runways, apron space and other aeronautical facilities at the Airport. At the same time, investment in CNS, ATM and related technological backbone for airborne and ground surveillance of the aircrafts were also planned. This called for a planned investment in Delhi Airport and the government embarked upon a journey of public private partnership as a procurement mechanism to augment Delhi's airport infrastructure.

\section{c. Project Objectives}

The key objective of Delhi Airport in general and Terminal 3 in particular was to build a world class International airport and provide a gateway for passengers coming to India via Delhi. In particular, there are four specific objectives, associated with Delhi Airport project. They are:

Institutional objectives: reduction of congestion by eliminating capacity constraints through balancing airside and landside demand and capacity.

Air passenger objectives: the infrastructure augmentation creates travel time savings and travel cost savings for passengers which results in efficiency whereas the decongested DIAL air space promotes the LCCs, enabling the common man to become airborne, thus fulfilling the equity objective of the airport.

Social objectives: as an economic asset, DIAL strengthens the social welfare of the national capital region by generating positive spillover effects in the community.

Economic objectives: are associated with ensuring the economic gains of the Government in leasing the airport to a private operator and re-investing the revenue earned from DIAL by building airports in the economically unfavorable locations or modernization of existing AAI managed airports. 


\section{d. Identification of the project}

The identification of an infrastructure project implies that the functions of the project should be clearly stated and it should be coherent with the objectives of the investment. Delhi International Airport Private Ltd. (DIAL) was formed with the objectives of operating, maintaining, developing, designing, constructing, upgrading, modernizing, financing and managing the Indira Gandhi International Airport, New Delhi. DIAL, the Integrated Brownfield Airport Project is comprised of three separate terminals - $1 \mathrm{~A}$ (for domestic flights of state owned Air India, MDLR and Go Air), 1B (was used by other domestic airlines, now closed and demolished), the Domestic Arrival Terminal (1C) and the newly-constructed 1D (now used by all remaining domestic airlines). There is also a separate Technical Area for WIP passengers. Additionally there is a separate terminal for Haj flights. Delhi Airport has two parallel runways and a near-parallel runway.

\section{e. Feasibility and Option Analysis}

The basis of any investment appraisal is to make a comparison between "with and without" the project. The core of benefit cost analysis is based upon the "with and without" approach and this in turn is grounded on the concept of opportunity cost. The best possible alternative solution on the basis of technical, regulatory and managerial constraints and demand opportunities, is the "do-something" alternative. This is the option which has been taken for the major brownfield project - DIAL.

\section{f. Financial Analysis}

The financial analysis is carried out through subsequent, interlinked accounts, referred to as the Integrated Documentation System (IDS) in the UNIDO Guide to Practical Project Appraisal, which is depicted in the figure in the following page.

In the financial analysis, it has been observed that though the net cash flow is still negative at 2012 , but the rate of inflows has grown in leaps from 7\% in $2010-2011$ to $30 \%$ in 2011-2012. The greatly increasing returns trades off the negative imbalance in net cash flows. This is a strong indication that the project is financially viable; with the prospect of earning increasing returns on investment as the project matures. This satisfies the first test of the success of a project, i.e., financial sustainability. 
The financial performance indicators are:

- Financial Net Present Value (investment) FNPV (C): INR (15016.35) CRORES, OR, -2252452500.00 USD

- Financial Net Present value (capital) FNPV (K): INR 1941.42 CRORES OR

\subsection{USD}

Figure 2: Structure of Financial Analysis (Source: EC Guide to CBA, 2008)

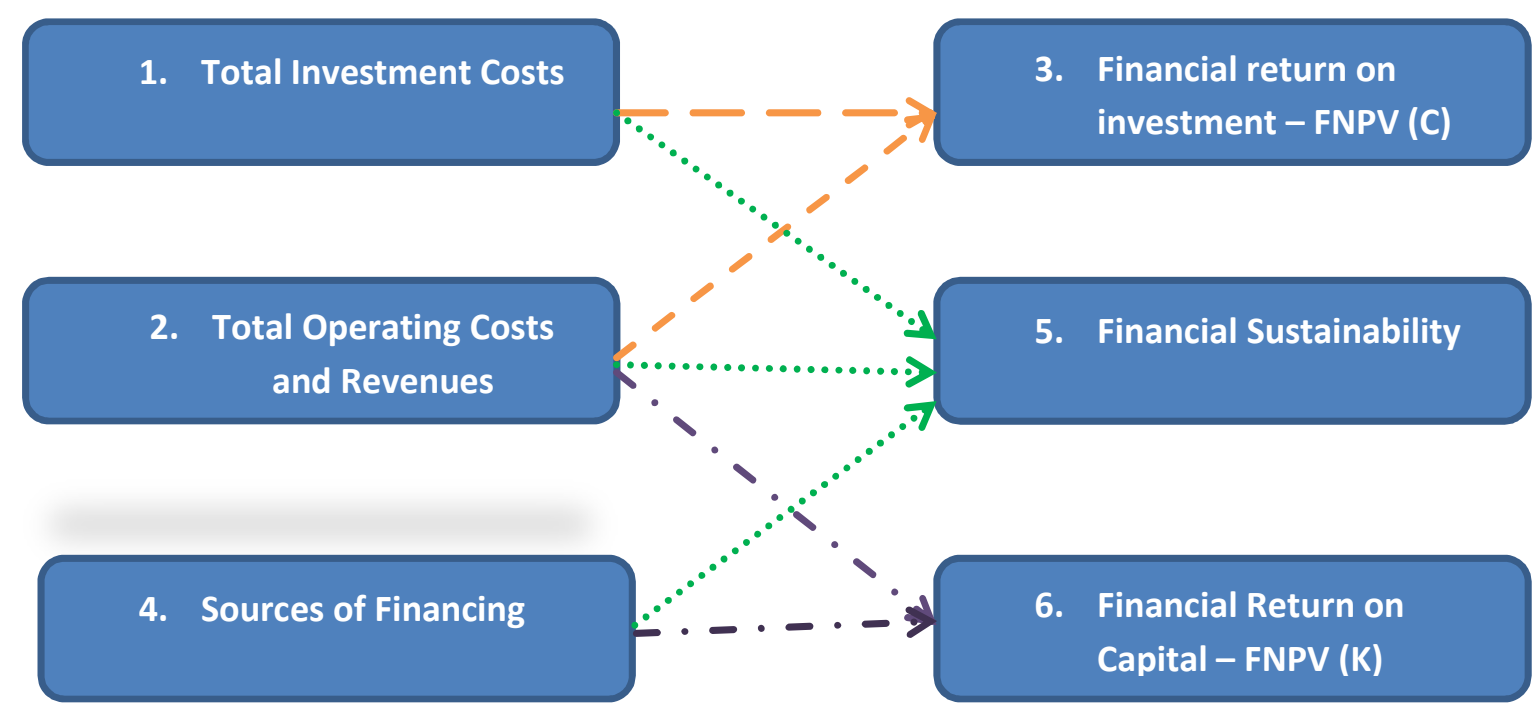

\section{g. Economic Analysis}

In the cost benefit appraisal of DIAL, the financial analysis of the project is followed by economic analysis. The analysis draws its merit from the concepts of consumers' surplus and rents, the distinction between benefits and transfer payments, the concept of shadow pricing, external economies and diseconomies, the choice of investment criteria and the problems of uncertainty are adequately covered in the succeeding sections.

The economic analysis is distinctly different from the financial analysis with respect to benefits accrued as a result of the project. Whereas the latter is merely concerned with the owners or promoters of the project, economic analysis attempts to identify the project's impact on the society at large. The fundamental premise on which the economic analysis is grounded, is based on the use of accounting prices (shadow prices), centered on the social opportunity cost, instead of observed distorted prices. This happens because observed 
prices of a project's inputs and outputs may not truly reflect the social opportunity cost (social value) like in case of imperfectly competitive markets. Financial data, though useful for project budgeting and financial control, may not be a good judge of welfare indicators of an economy.

To make a reasonably good Economic Analysis, it is equally important to consider the externalities that are not accounted for in the converted financial inputs and outputs. The sum total of the spillover effects as a result of the Delhi Airport megaproject is considered based on the direct, indirect and induced impact generated by airport construction and operational activities of DIAL. The qualitative aspects of these spillage effects have been attempted to capture under the umbrella of quantitative analysis.

\section{Consumer Surplus}

According to Alfred Marshall (1925), the consumer's surplus is the maximum sum of money the consumer would be willing to pay for a given amount of the good, less the amount he actually pays.

The consumers of an airport project are the airlines and the passengers. In these, airlines are the direct consumers in the sense that they interface with the operators on a daily basis in their transactions. The passengers are indirect consumers of airports; they patronize airlines flying in multitude directions and routes. The Consumer's Surplus of the DIAL project may be categorized in the following areas:

(a) Consumer Surplus (airlines) due to save in travel time, thus opening up new routes apart from existing schedules

(b) Consumer Surplus arising out of savings in Aircraft Operating Cost (AOC) in fuel expenses as a result of de-congested skies (less "go around" before receiving permission from ATNC to touch down)

(c) Consumer Surplus (Air Passengers) as a result of more flights, increased frequency of departures between Delhi and other metros and lower airfare stemming from competitive airlines market.

(d) Consumer Surplus (Air Passengers) as a result of saving in travel time.

(e) Consumer Surplus (passengers) in time savings as a result of intermodal switching (road/rail to air) in short haul routes like Delhi-Jaipur, Delhi-Chandigarh, Delhi- 
Gwalior, etc. Also, for the existing passengers in the same modes and routes, the road/rail corridor is now de-congested, so there is a lowering of the Vehicle Operating Cost (VOC) and savings in travel time too.

(f) It may be mentioned here that the VOC of the passengers travelling to T3, DIAL may slightly increase due to increased distance travelled to access and egress the new link to T3, however, this cost is offset by the reduction in travel time, as a result of Delhi Metro Railway Corporation and Delhi Metro Airport Express (Reliance Metro Airport Express Line) where the normal 60-80 minutes off peak hours drive has been reduced to 18 minutes for INR $80=00$ for a distance of 22 kilometers compared to normal taxi fare of INR $500=00$ for the same distance at a much lesser comfort and convenience.

\section{Producer Surplus}

New International airlines are now arriving and departing IGI Airport as a result of capacity expansion and modernization of New Delhi Airport. They are also adding new routes connecting India to other places on the global map. This increases the net aeronautical revenue for DIAL and generates producer's surplus on three counts. New airlines or increased routes increase the revenue model for DIAL. Due to expansion of capacity, marked by opening of the new routes and new entrees, there is considerably more passenger traffic, which greatly augments the Passenger Service Fee (PSF) and the User Development Fee (UDF) collected from the passengers. Thirdly, the growth in International (as well as domestic) passengers fuels the retail and miscellaneous sales of passenger facilities at the airport, thus boosting the non-aeronautical revenue stream for the airport developers and operators. This is the aggregate Producer's Surplus generated from the operation of DIAL.

\section{Government Surplus}

Government's surplus from this Brownfield infrastructure initiative comes from multiple avenues. Having a share of $44 \%$, as DIAL's revenue arises automatically Government's revenue also gets boost up. With the new terminal T3, additional flights and routes have opened at Delhi, bringing in additional passengers, thus having more tax revenues per passenger as well as from each airliner. 
Figure 3: Consumer Surplus as a result of reduced Generalized Cost

(Adapted from Mishan, 1976)

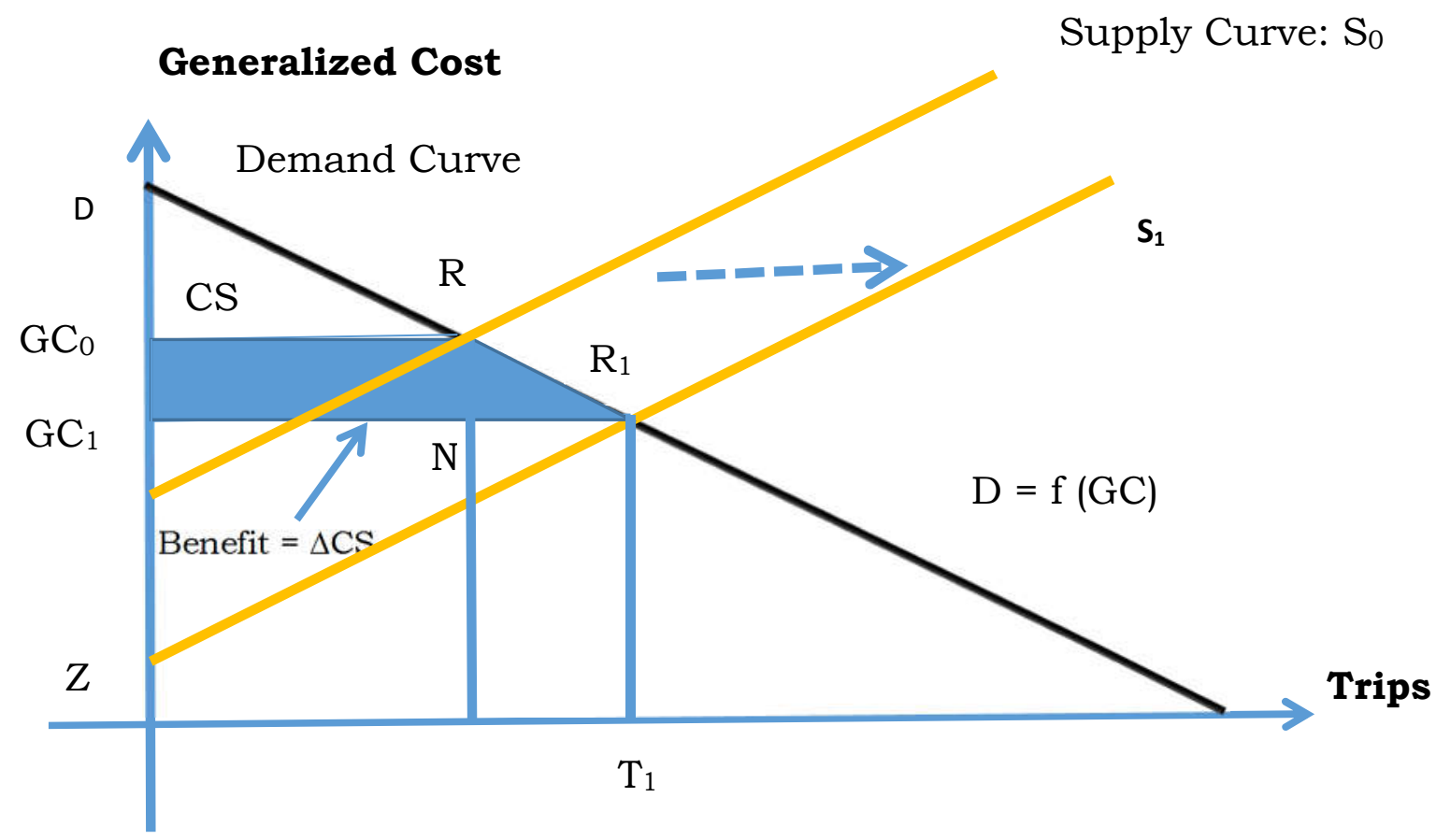

The above figure clearly explains the concept of Consumer Surplus in the specific case of DIAL. As a result of development of Delhi Airport as a Brownfield Project, there occur considerable scale efficiencies, thus lowering of prices from $\mathrm{OGC}_{0}$ to $\mathrm{OGC}_{1}$. The rectangle $\mathrm{GC}_{0} \mathrm{RNGC}_{1}$ is the resultant savings achieved by the existing airlines and its customers from the development of Delhi Airport, namely T3. Now let us consider the triangle RNR ${ }_{1}$. This part of the savings is brought about by the additional flights touching down and departing T3. These additional flights on new and existing routes and opening up new sectors for air travel further increases the competitiveness of airlines as compared to other modes of transportation like railways or roadways, thus substantially lowering down the price paid by the passengers toward the cost of air passage. This combined effect of cost saving (Consumer Surplus = Area of rectangle $\mathrm{GC}_{0} \mathrm{RNGC}_{1}+$ Area of triangle $\mathrm{RNR}_{1}=$ Area of enclosed figure $\mathrm{GC}_{0} \mathrm{RR}_{1} \mathrm{NGC}_{1}$ ) achieved by the airlines and passengers is expressed in the Generalized Cost Function.

Generalized Cost Function (GCF) is conveyed as the combination of the monetized and nonmonetized cost associated with a particular journey. Algebraically, GCF is expressed as: 
$\mathrm{GCF}=\dot{\mathrm{a}} \mathrm{T}+\beta \mathrm{L} \ldots(1)$

Where à $=$ value of time

$$
\begin{aligned}
& \mathrm{T}=\text { average travel time } \\
& \beta=\text { Vehicle Operating Cost (VOC) } \\
& \mathrm{L}=\text { travel distance }
\end{aligned}
$$

The triangle $\mathrm{DRGC}_{0}$ represents the consumer surplus $\left(\mathrm{CS}_{0}\right.$, which is beneath the demand curve and above the generalized equilibrium cost) before the commencement of the project. The $\mathrm{DR}_{1} \mathrm{GC}_{1}$ is the new area (larger than the earlier one) for consumer surplus, brought about by implementation of the airport project. Therefore, the User Benefit $=\mathrm{CS}_{1}-\mathrm{CS}_{0}$. We assume that with introduction of additional flights and new sectors and routes because of the new airport project, the supply curve will shift more toward the right (from $S_{0}$ to $S_{1}$ ) and hence the triangle $\mathrm{GC}_{1} \mathrm{R}_{1} \mathrm{Z}$ becomes the new producer surplus.

\section{h. Results of CBA for DIAL}

The Economic Performance Indicators of DIAL is given below.

- $\quad$ Economic Net Present Value (ENPV): INR 121,737.90 Crores (2006 - 2012)

- $\quad$ Economic Net Present Value (ENPV): INR 232800 Crores (2013 - 2017)

- $\quad$ B/C Ratio (Project Evaluation Phase: 2006 - 2012): 3.78

- $\quad$ B/C Ratio (Using discounted cash flow technique; 2013 - 2017): 8.15

The PPP of DIAL with the competition induced efficiency of the GMR led private partnership and the Government's effective monitoring and control has led to a synergy of relationships that ultimately gets reflected in the project evaluation and appraisal with regard to both the financial indicators and economic indicators. The performance indicators point to the fact that the project has been viable, both in the short-term as well as the future horizon of the lease period of 30 years till 2037. This work is a unique endeavor by itself, namely, the construction of finite elemental cost benefit analysis of an airport megaproject in India, which by all counts has been investigated for the first time in the area of airport infrastructure projects in India. 


\section{CONCLUSION}

The article presents a comprehensive analysis of the benefits and costs associated with the construction of Terminal 3 at Delhi Airport project (DIAL). The benefits include not only the financial gains of the stakeholders in the system, but also the economic gains to the National Capital Region (NCR) as a result of the increase in social welfare created by the DIAL T3.

Asian Development Bank (2007) observed that "countries differ in economic structure, capital scarcity, stage of financial development, efficiency of financial intermediation, impediments faced in accessing the international capital market, and social time preference." These differences result in varying SDRs and BCRs for airport infrastructure projects around the world. It may be worthwhile to examine the choice of social discount rates and the corresponding BCR for airport infrastructure projects across developed and developing economies to affirm the soundness of the results obtained in the CBA for Delhi Airport project.

The choice of the Social Discount Rate has significant impact on the outcome of BCR and Economic Net Present Value (ENPV). Economists across countries have applied a wide range of methodologies to get the SDR for a given infrastructure project. Prior to 1991, Australia used $8 \%$ SDR, and in recent times it follows the annually reviewed Social Opportunity Cost (SOC) Approach, which is less than $8 \%$. As against this Canada uses a SDR of $7 \%$, whereas in France it is 4\% based on the Social Rate of Time Preference (SRTP) Approach. In the case of Italy it is $5 \%$ and Spain $6 \%$ based on SRTP Approach. Coming to Norway and UK it is still lower at $3.5 \%$ based on rate of government borrowing and the SRTP Approach. Compared to these US Office of Management and Budget follows a SDR of $7 \%$. In the developing economies like Pakistan follows a 12\% SDR based on SOC Approach, Philippines $15 \%$ based on SOC Approach, China 8\% for Short and Medium Term Projects and less than $8 \%$ for Long Term Projects. In the present analysis, we have used a SDR of $10.81 \%$ using the SRTP Approach. There are significant variations in SDR policies in practice around the world based on the nature and the duration of the project, with developed countries applying lower rates (3-7\%) than the developing countries surveyed (8-15\%) and therefore our estimated value of $10.81 \%$ using SRTP Approach for a large scale and long term strategic infrastructure project like Delhi Airport that acts as major gateway, appears reasonable for a rapidly emerging economy like India. 
The SDR affects the outcome of the project like changes in Benefit Cost Ratios (BCR) as economic performance indicators of Delhi Airport project. A variation in the discount rate can considerably change the BCR as observed in the sensitivity analysis for Delhi Airport project's economic performance. An examination of the project BCRs of the airport infrastructure sectors across countries reveals an interesting observation. The East West Gateway Council of Government estimated a BCR of 10.90 for St. Louis Regional Airport, USA, which is primarily used for air freights. Florida Department of Transportation (2009), estimated a BCR of 7.3 for South West Florida International Airport using NPV for a 20-year design life and a 7\% discount rate. Graham (2013) of Imperial College, London mentions a BCR of about 5.6 for airports. A CBA was done for Rock County Airport in Southern Wisconsin by Wisconsin DOT to receive federal aviation funds from FAA for the airport expansion project. Technically it was a project appraisal which considered case of a runway expansion. The estimation of benefits and costs was undertaken using the Airport BenefitCost $(A B C)$ software, developed for Wisconsin DOT by Economic Development Research Group with Cambridge Systematics; using the state of Wisconsin's officially accepted 7\% discount rate. The sensitivity analysis of BCR varied between $3.23-5.27$ when compared and contrasted against the set of alternatives for Rock County Airport. PricewaterhouseCoopers (PwC) estimated the project BCR for Sunshine Coast Airport (SCA), Australia to vary in the range of 3.52 - 6.24. Management Research Centre University of Waikato Management School (2008) obtained a BCR in the range of 2.15 - 3.85 for Waikato Regional Airport. The underlying observation for these variances reveal that for air freight focused airports, the BCR often assumes a double digit value and for passenger airports the $\mathrm{BCR}$ lies in the range of $2-5.6$, which is specific to the macroeconomic context of the country, with due weightage to the nature of the project and its duration. These observations validate our BCR estimation of 3.78 for Delhi Airport and confirm the soundness of the estimate.

The financial and economic benefits have therefore been well justified in the results and highlights the worth of PPP in airport infrastructure projects in India.

\section{ACKNOWLEDGMENT}

We would like to express our sincere thanks to Airports Economic Regulatory Authority of India (AERA) for giving us the opportunity of undertaking this research project, which proved to be challenging and involved. In particular, we are grateful to Shri. Yashwant 
Bhave, Former Chairperson, Capt. Kapila Chaudhuri, Former Secretary, Shri. MP Vijaya Kumar, Member and Shri. C V Deepak of AERA for their helpful role. We would also like to acknowledge Remsons Centre for Management Research, Durgadevi Saraf Institute of Management Studies, Mumbai for their scholastic support.

\section{REFERENCES}

Aschauer, D. A. (2001), "Output and Employment Effects of Public Capital," in Public Finance and Management, Symposium on Public Capital, from http://www.spaef.com/PFM PUB/v1n2.html

Asian Development Bank (2011), Economic Analysis, National Grid Improvement Project, RRP IND 44426 and 44917, accessed from http://www2.adb.org/Documents/RRPs/IND/44426/44426-014-ind-ea.pdf on 1 December 2012

Christian von Hirschhausen (2002), "Modernizing Infrastructure in Transformation Economies: Paving the Way to European Enlargement," Edward Elgar Publishing, USA

Estache A, M. Romero and Strong J (2002), "The Long and Winding Path to Private Financing and Regulation of Toll Roads," World Bank Institute Policy Research Working Paper 2387, Washington D C: World Bank

Grimsey, D. and M. K. Lewis (2002), "Evaluating the Risks of Public Private partnerships for Infrastructure Projects," International Journal of Project Management, Vol. 20(2), pp. 107 118

Kay, J (1993), "Efficiency and Private Capital in the Provision of Infrastructure," in Infrastructure Policies for the 1990s, Paris: Organization for Economic Cooperation and Development, pp. $55-73$

Milbourne, R., G. Otto and G. Voss (2001), "Public Investment and Economic Growth, from http://web.uvic.ca/ gvoss

Mishan E J (1976), "Cost-benefit analysis: an informal introduction," London: Allen \& Unwin Musgrave, R. A. (1959), "The Theory of Public Finance - A Study in Public Economy, New York: McGraw Hill

Stiglitz, J. E. (2000), "Economics of the Public Sector," W.W. Norton, 3rd Edition 
Threadgold, A. (1996), "Private Financing of Infrastructure and Other Long Term Capital projects," Journal of Applied Finance and Investment, Vol. 1(1), pp. $7-12$

Winston, Clifford (2006), "Government Failure versus Market Failure: Microeconomics Policy Research and Government Performance," The Brookings Institution, Washington DC

Wolf Hartmut (2008), "Airport Alliances and Multi Airport Companies - Implications for Competition Policy," accessed from http://www.hamburg-aviation-conference.de

World Bank (1994), "World Bank Development Report 1994: Infrastructure for Development, New York: Oxford University Press, accessed from www.europa.eu.int

Yeaple, S. and Golub S. (2002), International Productivity Differences, Infrastructure, and Comparative Advantage, from http://www.econ.yale.edu/seminar/trade/tdw02/yeaple021216.pdf

Yescombe E. R. (2007), "Public - Private Partnerships: Principles of Policy and Finance, Butterworth - Heinemann, Oxford, UK

\section{Reports and Guidelines}

Evaluation Unit, DG Regional Policy, European Commission (July 2008), Guide to CostBenefit Analysis of investment projects: Structural Funds, Cohesion Fund and Instrument for Pre-Accession, accessed from

http://ec.europa.eu/regional_policy/sources/docgener/guides/cost/guide2008_en.pdf

\section{Websites for Reports/White Papers/Financial Information}

Airport Economic Regulatory Authority, http://www.aera.gov.in

Airports Authority of India, http://www.aai.aero

Centre for Monitoring Indian Economy (CMIE), www.cmie.com

Ministry of Civil Aviation (MOCA), www.civilaviation.gov.in

Ministry of Statistics and Programme Implementation (MoSPI),

http://www.mospi.nic.in

National Council of Applied Economic Research, http://www.ncaer.org

Trading Economics, http://www.tradingeconomics.com 


\section{Websites for Travel Price (Fare) Information}

Kayak.co.in; MakeMyTrip.com; Yatra.com; TripAdvisor.in; ClearTrip.com; Travelguru.com; Expedia.co.in; Ezeego1.co.in; Ixigo.com; TravelMasti.com; Orbitz.com 